\title{
Catalytic Kabachnik-Fields reaction: new horizons for old reaction
}

\author{
Nikolay S. Zefirov and Elena D. Matveeva* \\ Department of Chemistry, Moscow State University, Moscow, Russia \\ E-mail: matveeva@org.chem.msu.ru, zefirov@org.chem.msu.ru
}

\begin{abstract}
Overview of data, obtained in the last 7 years, concerning the mechanistic aspects, the catalyzed versions and the synthetic potential of the Kabachnik - Fields reaction are discussed.
\end{abstract}

Keywords: Kabachnik - Fields reaction, mechanism, $\alpha$-aminophosphonates, tetra-tertbutylphthalocyanines aluminum and chromium complexes

\section{Contents}

1. Introduction

2. Mechanistic details and general scope of the Kabachnik-Fields reaction

2.1.Mechanistic summary

2.2. Conditions and catalysis

2.3. Amino-component

2.4. Carbonyl-component

2.5. Phospho-containing component

2.6. Unexpected products in a Kabachnik-Fields synthesis of aminophosphonates

3. Synthetic application of phthalocyanine catalyzed variant of Kabachnik - Fields reaction

3.1 Variation of carbonyl component

3.2 Variation of amino component
(a)Benzylamine and ammonium carbonate
(b)Heterocyclic components
(c) Aminoacids and their esters
(d) Peptides
(e) Miscellaneous amino compounds

4. Conclusions 


\section{Introduction}

$\alpha$-Aminophosphonic acids may be considered as phosphorus analogues of $\alpha$-amino acids ("bioisosterism") and have received considerable attention owing to their pronounced biological activities. These compounds have been shown to serve as inhibitors of GABA receptors, inhibitors of various proteolytic enzymes, inhibitors of dialkylglycine decarboxylase, as peptide mimetics, haptens of catalytic antibodies, antibiotics, and pharmacological agents, including antitumor, antihypertensive and antibacterial ones. ${ }^{2,3 \mathrm{e}}$

Various synthetic methods for $\alpha$-aminophosphonic acids and $\alpha$-aminophosphonates have been reported ${ }^{20,3}$ and the straightforward one is the addition of the compounds, containing $\mathrm{P}-\mathrm{H}$ bond to the $\mathrm{C}=\mathrm{N}$ - bond of imines (Pudovik reaction, ${ }^{4}$ Scheme $1 \mathbf{A}$ ). In fact, dialkyl phosphites are able to undergo many addition reactions, including addition to the $\mathrm{C}=\mathrm{O}$ bond to give $\alpha$ hydroxyphosphonates (Abramov reaction, ${ }^{5}$ Scheme 1B).

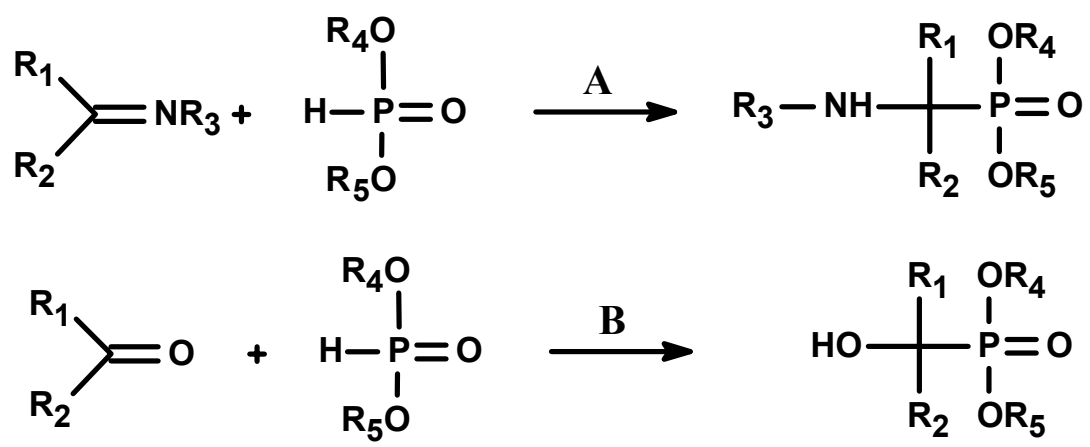

\section{Scheme 1}

However, the most remarkable pathway to the synthesis of $\alpha$-aminophosphonates is the Kabachnik-Fields reaction, ${ }^{6,7}$ which is a one-pot, three-component procedure using carbonyl compound, amine and dialkyl phosphite (Scheme 2).

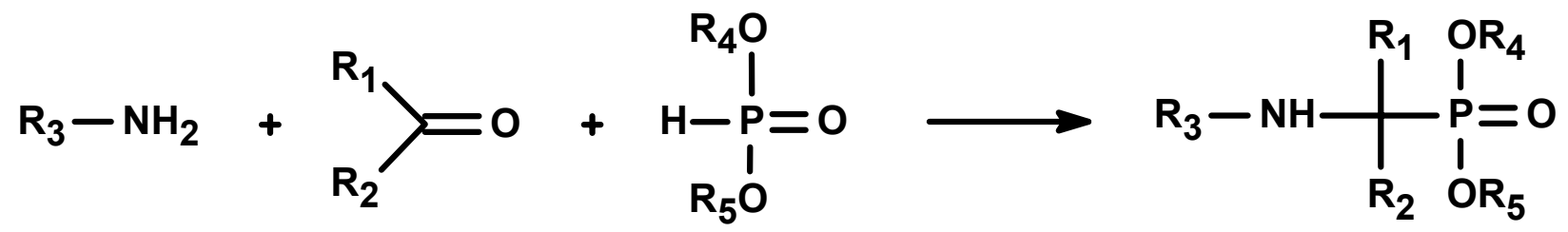

\section{Scheme 2}

This process was discovered at a time, when multicomponent processes were rather "exotic birds"; from a modern point of view this protocol is obviously very attractive for combinatorial chemistry and has been rarely used for parallel synthesis. ${ }^{8}$ 
This approach is especially satisfactory for reactions with aldehydes $\left(\mathrm{R}_{1}=\mathrm{H}\right)$; in contrast, only few examples of the Kabachnik-Fields reaction of rather simple ketones (mainly, acetone, acetophenone and cyclohexanone) ${ }^{9}$ have been documented. Thus, the synthetic potential of the Kabachnik-Fields reaction had not been developed in full scale in the 20th century.

The new avenue could be connected with an elaboration of catalytic procedures [vide infra]. Starting in 2003 we have been developing a novel effective catalytic variant of the synthesis of $\alpha$-aminophosphonates in the presence of tetra-tert-butylphthalocyanines (tPcM) (Figure 1) as the catalyst, the aluminum and chromium complexes, $\mathrm{tPcAlCl}$ and $\mathrm{tPcCrCl}$, being usually the most active. $^{10}$

This finding gave us the proper tool to drastically increase the scope of the Kabachnik-Fields reaction. In this review we would like to: (1) briefly summarize the mechanistic data as well as the scope and limitation of the classic procedure, and (2) describe the synthetic applications of our catalytic variant of this reaction.

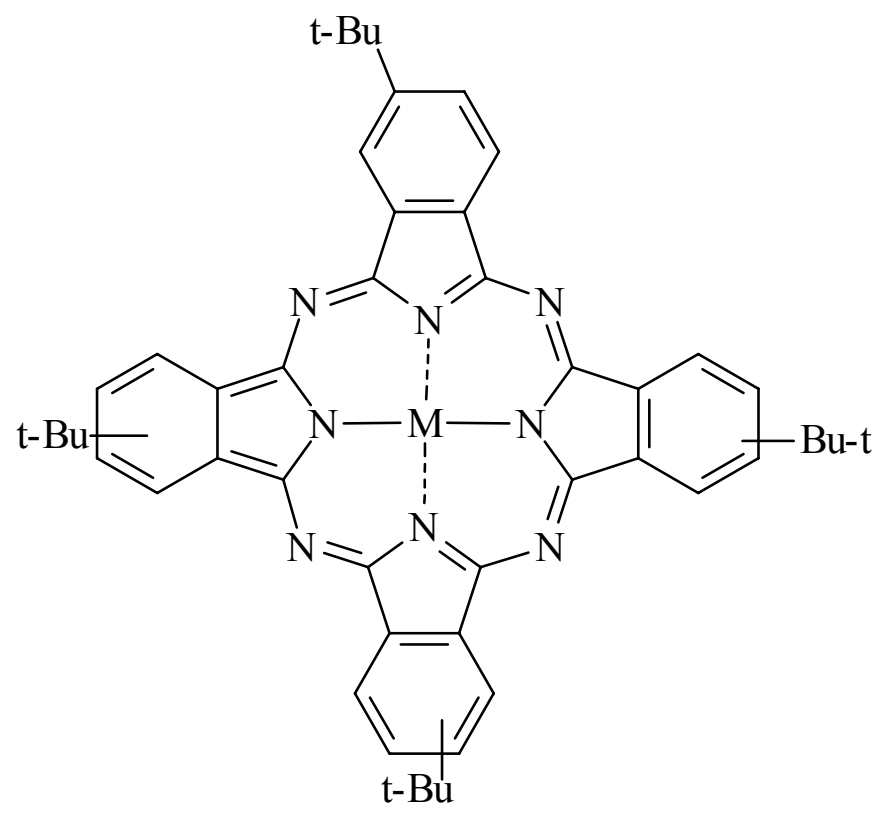

\section{Figure 1}

\section{Mechanistic details and general scope of the Kabachnik-Fields reaction}

As it was mentioned above, this reaction is the one-pot, three-component procedure, which includes: (a) carbonyl compound, (b) amine and (c) dialkyl phosphite and proceeds in accordance with general Scheme 2. This reaction has been studied in detail and thoroughly reviewed. $^{7,11}$ Here we present only essential summary of important characteristics of this reaction. 


\subsection{Mechanistic summary}

Obviously, this reaction is, in reality, a multistep procedure having quite a complex mechanism (Scheme 3). 7,11,12

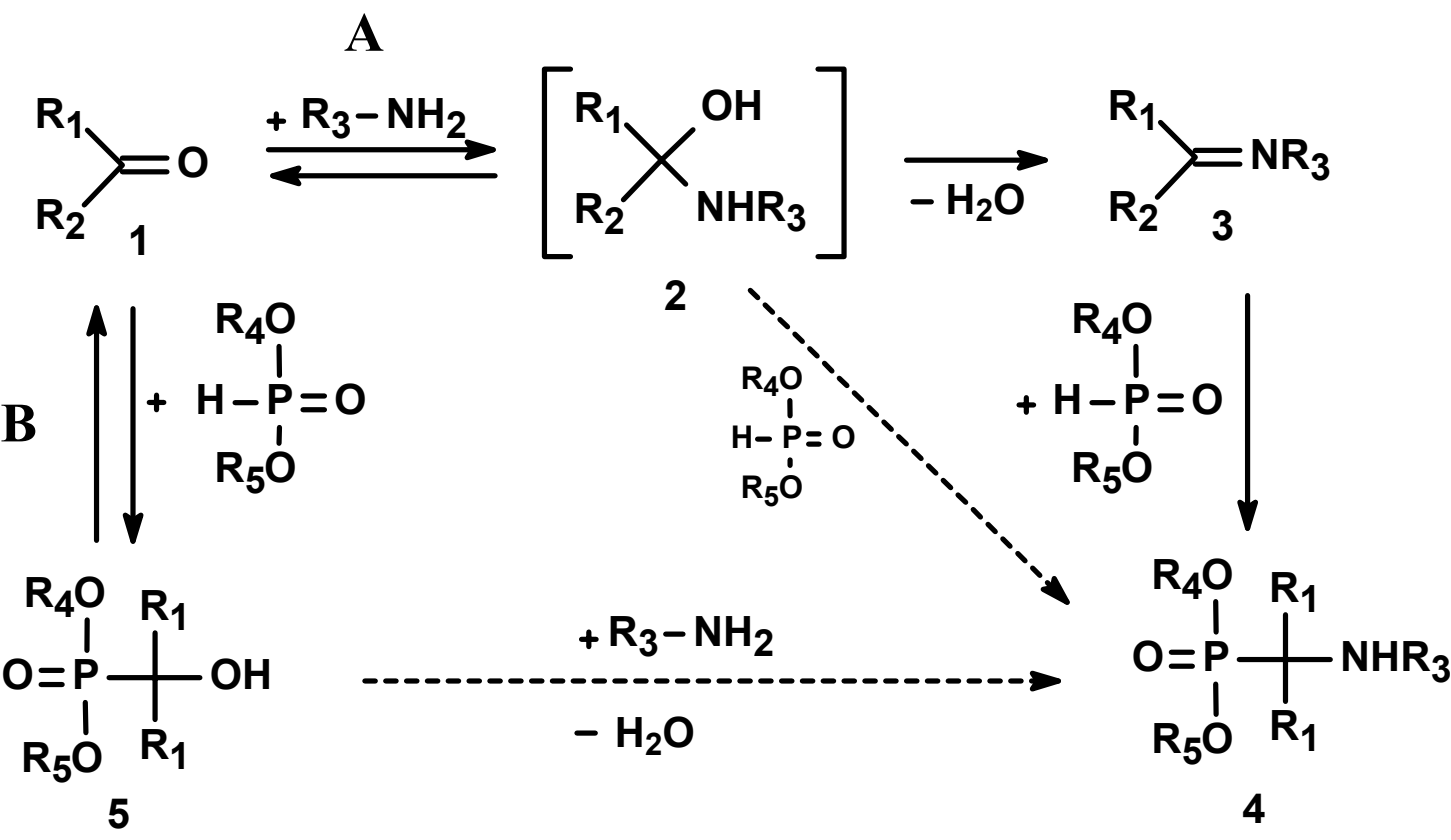

\section{Scheme 3}

Indeed, it was reasonably supposed, that the first step is the formation of the corresponding imine 3 (Pathway A). Because its formation is a reversible process, the application of any means, permitting the elimination of the water formed (vide infra) is helpful for the whole process. In the second step the compounds having $\mathrm{P}-\mathrm{H}$ bond adds to the $\mathrm{C}=\mathrm{N}$ bond of the transient imine 3 , following with Pudovik type of addition $(\mathbf{3} \rightarrow \mathbf{4})^{4}$ to give phosphonates $\mathbf{4}$ as the final product (Scheme 3).

One of possible complications of the Kabachnik-Fields reaction is also obvious: the dialkyl phosphites are able to undergo Abramov addition to $\mathrm{C}=\mathrm{O}$ bond, giving $\alpha$-hydroxyphosphonates 5 (Scheme 2, path B). ${ }^{5,7,9,11}$ Thus, in the case of three-component process one is faced with competitive addition of either $\mathrm{N}-\mathrm{H}$ or $\mathrm{P}-\mathrm{H}$ fragments to $\mathrm{C}=\mathrm{O}$ bond. This dichotomy was mentioned and discussed in terms of hard $(\mathrm{N}-\mathrm{H})$ and soft $(\mathrm{P}-\mathrm{H})$ bases. ${ }^{7,9 b}$ Sometimes the authors claimed, that the Abramov pathway can also lead to the product 4 of Kabachnik-Fields reaction ${ }^{7}$ and even considered the direct nucleophilic substitution of the hydroxyl in $\alpha$ hydroxyphosphonates by amino component ("nucleophilic amination" of $\alpha$-hydroxy phosphonates $\mathbf{5} \rightarrow \mathbf{4}$ ). ${ }^{11,12}$ To the best of our knowledge, the pathway $\mathbf{2} \rightarrow \mathbf{4}$ has not been discussed in the literature. Some arguments for nucleophilic an amination pathway $\mathbf{5} \rightarrow \mathbf{4}$ came also from stereochemical consideration. ${ }^{12}$ On the other hand, there is an experimental disapproval of this 
suggestion for some cases. ${ }^{11,12}$ In any case, there is still the possibility for the formation of $\alpha$ aminophosphonates $\mathbf{4}$ taking into account the possible reversibility the Abramov process. ${ }^{11}$

\subsection{Conditions and catalysis}

The standard procedure usually includes the reaction of equimolar quantities of all components in the appropriate solvent (e.g. benzene, toluene, isopropanol), with or without removal of water by azeotropic distillation. The novel trends in carrying out this reaction are connected with the application of (i) microwave irradiation itself or in combination with catalyst, ${ }^{13}$ (ii) ionic liquids as solvents, ${ }^{14}$ (iii) use of appropriate dehydrating agents ${ }^{15}$ (e.g. $\mathrm{MgSO}_{4}{ }^{15 \mathrm{a}}$ or molecular sieves $^{10 f, i, 15 b, c}$ ) and, probably most important, (iv) the use of catalysts.

Acids, and especially Lewis acids are effective catalysts for Pudovik reaction. ${ }^{16}$ However, their application in one-pot Kabachnik-Fields reaction is not straightforward, because water forming during imine formation can deactivate the Lewis acid. This problem was solved either by co-use of catalyst with dehydrating agent or by application of catalysts being stable in water, as, for example, some rare earth metal triflates. Indeed, a variety of such combinations were suggested as catalysts, e.g. lanthanide triflates $/ \mathrm{MgSO}_{4},{ }^{15 \mathrm{a}}$ metal triflates/no solvent, ${ }^{17 \mathrm{a}} \mathrm{InCl}_{3},{ }^{17 \mathrm{~b}}$ scandium (tris-dodecyl sulfate), ${ }^{17 \mathrm{c}} \mathrm{TaCl}_{5}-\mathrm{SiO}_{2},{ }^{17 \mathrm{~d}} \mathrm{Ln}(\mathrm{OTf})_{3}$-ionic liquid, ${ }^{14 \mathrm{~b}}$ lanthanide triflates/ionic liquids, ${ }^{14 \mathrm{c}} \mathrm{SmI}_{2},{ }^{15 \mathrm{c}} \mathrm{AlCl}_{3} .{ }^{17 \mathrm{e}}$ The majority of these processes were satisfactory mainly for aldehydes; the examples of ketones have included only few examples of the simple ones.

It is of interest that catalytic acceleration using rather unusual catalysts was also documented in this reaction (crown ethers, ${ }^{18 \mathrm{a}, \mathrm{b}}$ montmorillonite $\mathrm{KSF} /$ microwave, ${ }^{18 \mathrm{c}} \mathrm{Al}_{2} \mathrm{O}_{3} /$ microwave, ${ }^{13 \mathrm{a}}$ $\mathrm{SiO}_{2} /$ microwave, ${ }^{18 \mathrm{~d}}$ derivatives of thiourea, ${ }^{18 \mathrm{e}} \mathrm{Me}_{2} \mathrm{~S}^{+} \mathrm{BrBr}^{-}{ }^{-18 \mathrm{f}}$

\subsection{Amino-component}

Ammonia, ${ }^{3 e, 7}$ it's silylated derivatives ${ }^{19}$ as well as a great variety of aliphatic, aromatic and heterocyclic amines were successfully used as the amino-component in this reaction. ${ }^{3 \mathrm{e}, 7,20}$ Here we just indicate some examples of interest as dicyanoethylamine, ${ }^{20 a}$ trans-1,2diaminocyclohexane, ${ }^{20 \mathrm{~b}}$ aminoadamantanes, ${ }^{20 \mathrm{c}}$ aminopyridines, ${ }^{20 \mathrm{~d}}$ aminotetrazoles, ${ }^{20 \mathrm{e}}$ aminobenzofurazanes, ${ }^{20 \mathrm{f}}$ phosphorylation of chitosan, ${ }^{20 \mathrm{~g}}$ crosslinked polyaminomethylstyrene, ${ }^{20 \mathrm{~h}}$ amino derivatives of calyx[4]arene, ${ }^{20 j}$ etc. We emphasize the finding that some aminoacids can play this role in a reaction with formaldehyde as the carbonyl component. ${ }^{21}$

\subsection{Carbonyl-component}

As it was stated above, this approach is especially satisfactory for reactions with aldehydes $\left(\mathrm{R}_{1}=\mathrm{H}\right.$, Scheme 1). Especially formaldehyde and benzaldehyde were used as sort of standard for this process. Let us to mention the use of salicyl- ${ }^{11 \mathrm{c}}$ and 3-indol- ${ }^{18 \mathrm{~b}}$ aldehydes. In contrast, only 
there are scarce examples of Kabachnik-Fields reaction of rather simple ketones (mainly, acetone, acetophenone and cyclohexanone) with appreciable formation of $\alpha$ hydroxyphosphonates $5^{9 \mathrm{a}}$ has been documented. It is of interest, that nitroso group, $-\mathrm{N}=\mathrm{O}$ can play role of a carbonyl component in this reaction to give corresponding hydrazides of diethylphosphoric acid. $^{22}$

\subsection{Phospho-containing component}

This reaction was studied mainly for symmetrical dialkyl phosphites (Scheme 2, $\mathrm{R}_{4}=\mathrm{R}_{5}$ ). However there are publications describing the involvement of some other $\mathrm{P}-\mathrm{H}$ containing compounds, such as $\mathrm{HP}(\mathrm{O})(\mathrm{OH})_{2}, \quad \mathrm{H}_{3} \mathrm{PO}_{2}, \quad \mathrm{H}_{2} \mathrm{P}(\mathrm{O}) \mathrm{OR},{ }^{23 \mathrm{a}} \quad \mathrm{R}_{2} \mathrm{PHO},{ }^{11 \mathrm{e}}$ alkyl alkynylphosphonites, ${ }^{23 \mathrm{~b}}$ ethyl benzoyloxymethyl hydrogenophosphinate, ${ }^{23 \mathrm{c}}$ (RO) ${ }_{4} \mathrm{P}-\mathrm{H},{ }^{23 \mathrm{~d}}$ hypophosphites ${ }^{23 \mathrm{e}}$ and even $\mathrm{PCl}_{3},{ }^{7}$ into this reaction.

\subsection{Unexpected products in a Kabachnik-Fields synthesis of aminophosphonates}

The formation of side products usually connected with the transient formation of $\alpha$ hydroxyphosphonates, their rearrangement to the corresponding phosphates and their amine promoted decomposition/s, leading to a number of unexpected products. In some cases (e.g. benzophenone) they could be the only products of the reaction., ${ }^{9,24}$

\section{Synthetic application of phthalocyanine catalyzed variant of Kabachnik - Fields reaction}

As it was mentioned above, we have been developing a novel effective catalytic variant of the synthesis $\alpha$-aminophosphonates in the presence of tetra-tert-butylphthalocyanines (tPcM) as the catalyst. ${ }^{10}$ Now we shall describe the possibilities provided with this protocol to enhance the scope and limitation of the classic procedure.

\subsection{Variation of carbonyl component}

We have shown that a great variety of ketones react with benzylamine and diethyl phosphite leading up to $\alpha$-benzylaminophosphonates in very high yields $(50-98 \%) .{ }^{10} \mathrm{~A}$ representative set of ketones, which were employed in the synthesis $\alpha$-benzylaminophosphonates are shown in Table 1 . The data of the Table 1 evidences firstly that a variety of ketones, containing fivemembered (entries 8-12,14) or six-membered rings (entries 1-3, 6,7, 15-18) are a good carbonyl component in this reaction, including bi- or polycyclic ketones (entries 7-9, 18) as well as ketones conjugated with aromatic rings (entries 6, 10-15). Entries 16 and 17 show that heterocyclic ketones smoothly react in this reaction. Analogously, $\alpha, \beta$-unsaturated aldehydes and ketones also react to give exclusively $\alpha$-aminophosphonates (entries 21-24, Table 1). Entry 5 
shows, that cyclopropyl group is untouched during this process. As it was expected, the complication of carbon skeleton of ketones and increasing of steric hindrance leads to smoothly dropping yields of $\alpha$-aminophosphonates (in the cases of entries 4 and 9 in Table 1). Entries 4, 8, 9 clearly demonstrate that steric hindrance does not prohibit the reaction.

Furthermore, the dicarbonyl compounds can also play role of carbonyl component in this reaction. Depending on mutual position of $\mathrm{C}=\mathrm{O}$ groups, the reaction affects either one (entry 17) or both (entries 18-21) carbonyls.

Table 1. Applied ketones and the corresponding product

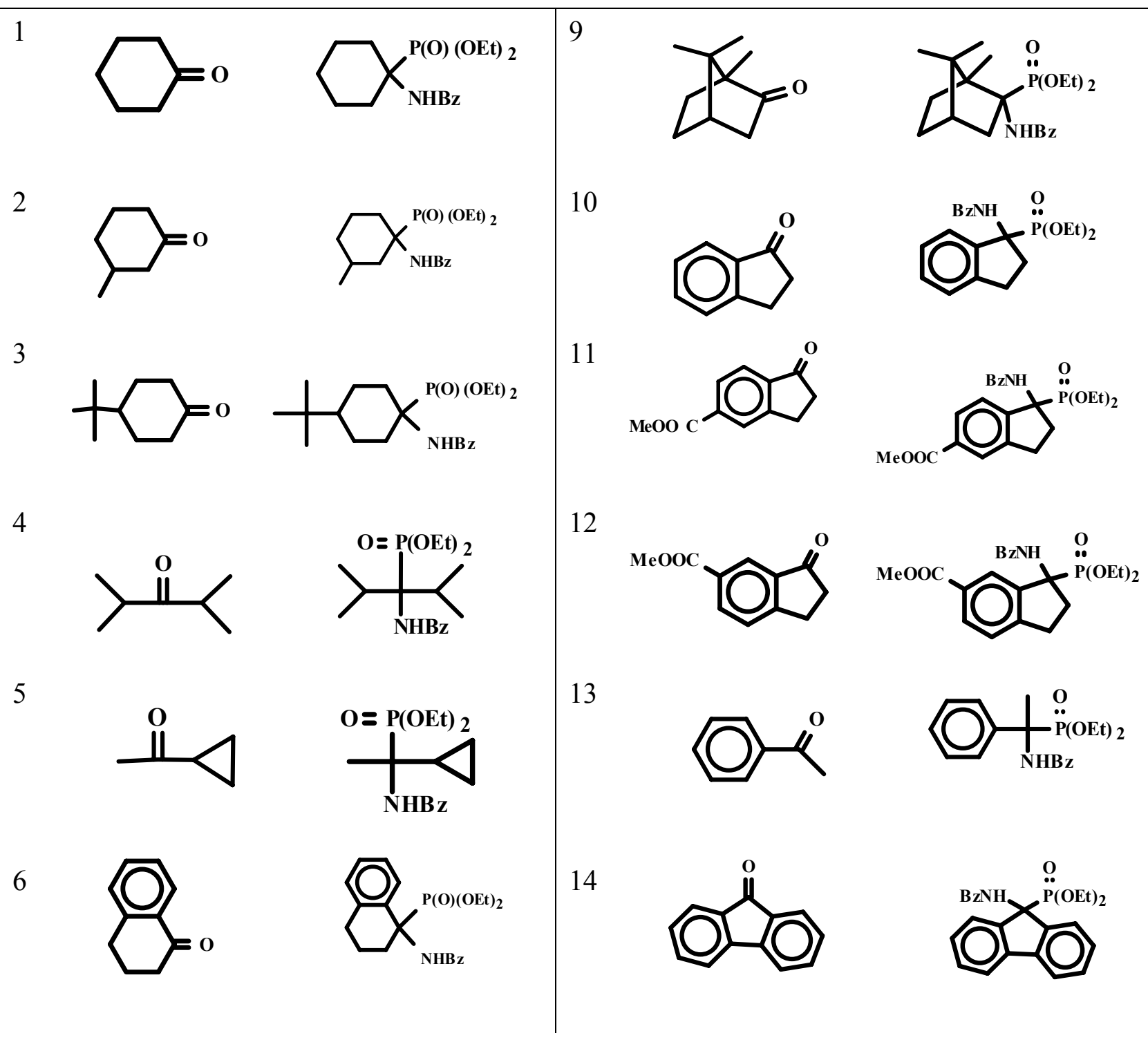


7<smiles>O=C1C2CC3CC(C2)CC1C3</smiles><smiles>CCCC[PH2+]C1(CCCC)C2CC3CC(C2)CC1C3</smiles>

8<smiles>O=C1CC2CCC1C2</smiles>

17<smiles>O=C1Nc2ccccc2C1=O</smiles>

18<smiles>CC12CCC(=O)C=C1CCC1C2C(O)CC2(C)C1CCC2(O)C(=O)CO</smiles>

19<smiles>O=C(C(=O)c1ccccc1)c1ccccc1</smiles>

20<smiles>O=C1c2ccccc2C(=O)c2ccccc21</smiles>

21<smiles>O=C1C=CC(=O)C=C1</smiles>

22



15<smiles>O=C1c2ccccc2Cc2ccccc21</smiles><smiles>CCOC(=O)C1([18NH])c2ccccc2Cc2ccccc21</smiles><smiles>CC(C)CN1CCC(=O)CC1</smiles>

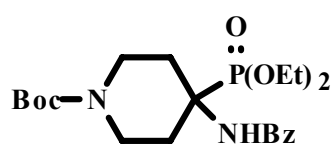



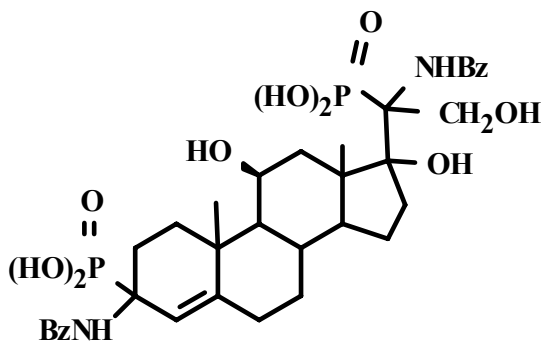

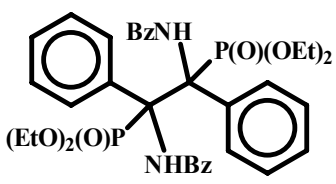

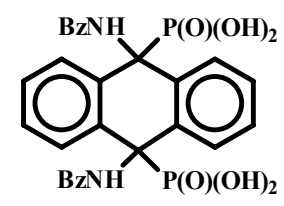

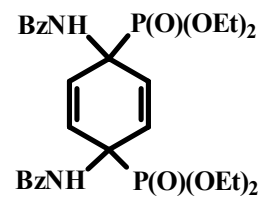<smiles>CCOC(=O)C(/C=C/c1ccccc1)NCCO</smiles> 
23
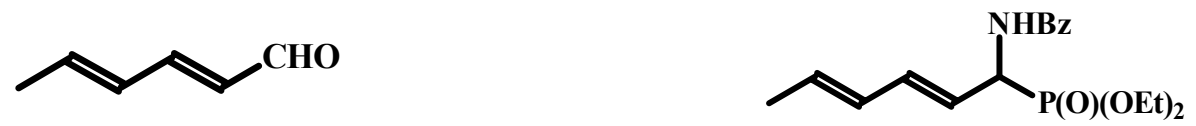

24
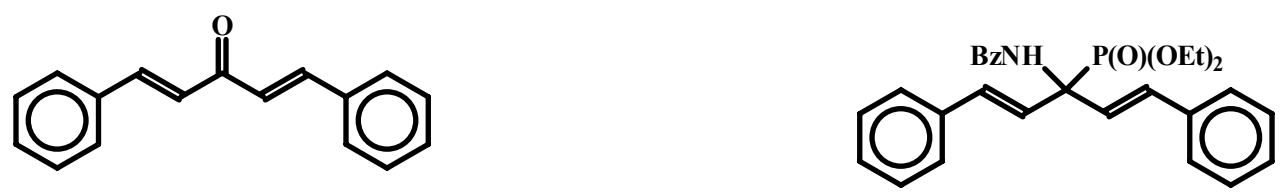

25
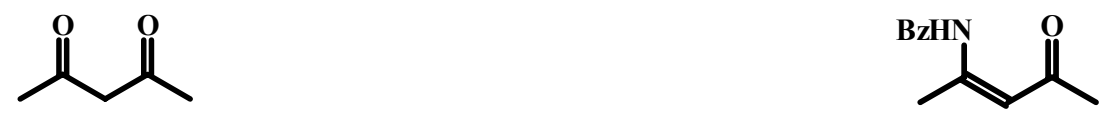

26
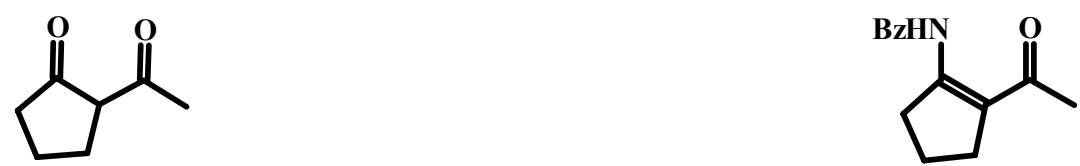

\subsection{Variation of amino component}

(a) Benzylamine and ammonium carbonate. We have used benzylamine as the universal model amino component in our catalytic variant of Kabachnik-Fields reaction. Its selection was due to two reasons: (1) it reacts smoothly for all cases, and (2) the hydrogenolysis of the products gave the products with free amino group. ${ }^{10 a}$ However we also developed a convenient reaction leading directly to $\alpha$-aminophosphonates containing unsubstituted amino group using ammonium carbonate as the amino component (for the followings ketones: 1-4, 6-8, 10,12,13, Table 1). ${ }^{10 a, b}$

What is more, the $\alpha$-aminophosphonates obtained can be transformed into corresponding $\alpha$ aminophosphonic acids. The pathway includes hydrolysis of esters with $\mathrm{HBr}$ with the following dehydrobromination by propylene epoxide as follows: ${ }^{10 a}$

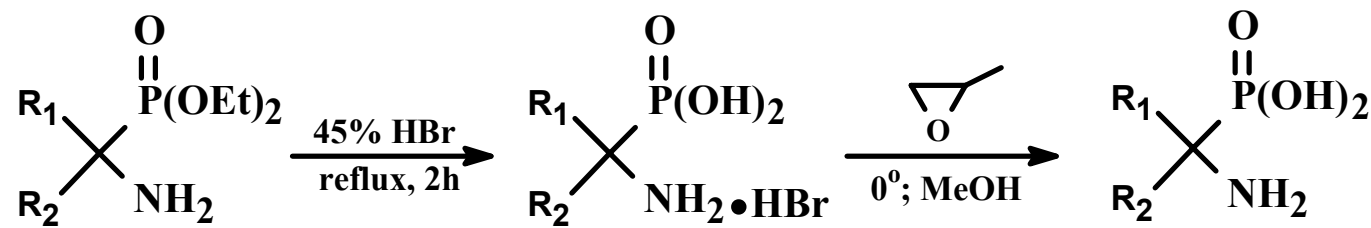

(b) Heterocyclic components. We have shown that heterocyclic amines, even those with reduced nucleophilicity such as 2-aminopyridine, may be successfully used in the catalytic Kabachnik-Fields reaction (in fact, the use of this amine has not yet been reported in the literature). The obtained new heterocyclic $\alpha$-aminophosphonates from corresponding aldehydes of indol- and pyridine series are shown in Table 2. 
Table 2. Applied heterocyclic compounds and the corresponding product

1<smiles>Cn1c(C=O)cc2ccccc21</smiles>

2<smiles>O=Cc1c[nH]c2ccccc12</smiles>

3<smiles>N#CCCn1cc(C=O)c2ccccc21</smiles>

4

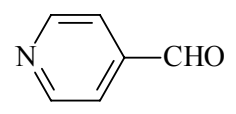

5

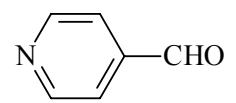

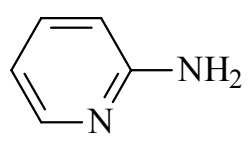<smiles>CCOc1cc2ccccc2n1CC(C)Nc1ccccn1</smiles><smiles>CCOCC(Nc1ccccn1)c1c[nH]c2ccccc12</smiles><smiles>CCOCC(Nc1ccccn1)c1cn(CCC#N)c2ccccc12</smiles><smiles>CCOCC(Nc1ccccn1)c1ccncc1</smiles>

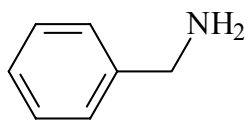

(c) Aminoacids and their esters. We have shown, that one can successfully use aminoacids and their esters as amino component in the reaction under study (Table 3) ${ }^{10 \mathrm{f}, \mathrm{h}, \mathrm{i}}$. At first, the reactions of benzaldehyde and p-trifluoromethylbenzaldehyde with ethyl ester of glycine gave the corresponding $\alpha$-amino-phosphonates (entries 1-2). Side formation of diketopiperazines can be sharply reduced with application of tert-Bu esters. Reactions of octanal (entries 6 and 14) with tert-Bu esters of alanine and phenylalanine demonstrate the application of this process to aliphatic aldehydes. What is more, these two esters were successfully involved into reactions with ketones, such as acetophenone, indanone and methyl cyclopropyl ketone.

What is more, even free aminoacids (but not only their esters!) can also react to give the corresponding $\alpha$-aminophosphonates with free carboxyl (entries 10,11,18 and 19).

Finally, the example (Table 3, entry 22) interestingly demonstrates, that one can use the difference in reactivities of formally available amino groups. 
(d) Peptides. As an extension, we have tried to use the di- and tri-peptides having free amino group as the amino component in our catalytic variant of Kabachnik-Fields reaction (Table 3). One can see that dipeptides can be successfully used in this reaction (entries 20,21).

Finally, the example of successful application of tripeptide (entry 23) clearly demonstrates that a synthetic potential of this old reaction is great and need more investigations.

Table 3. Applied aminoacids, their esters, peptides and the corresponding product

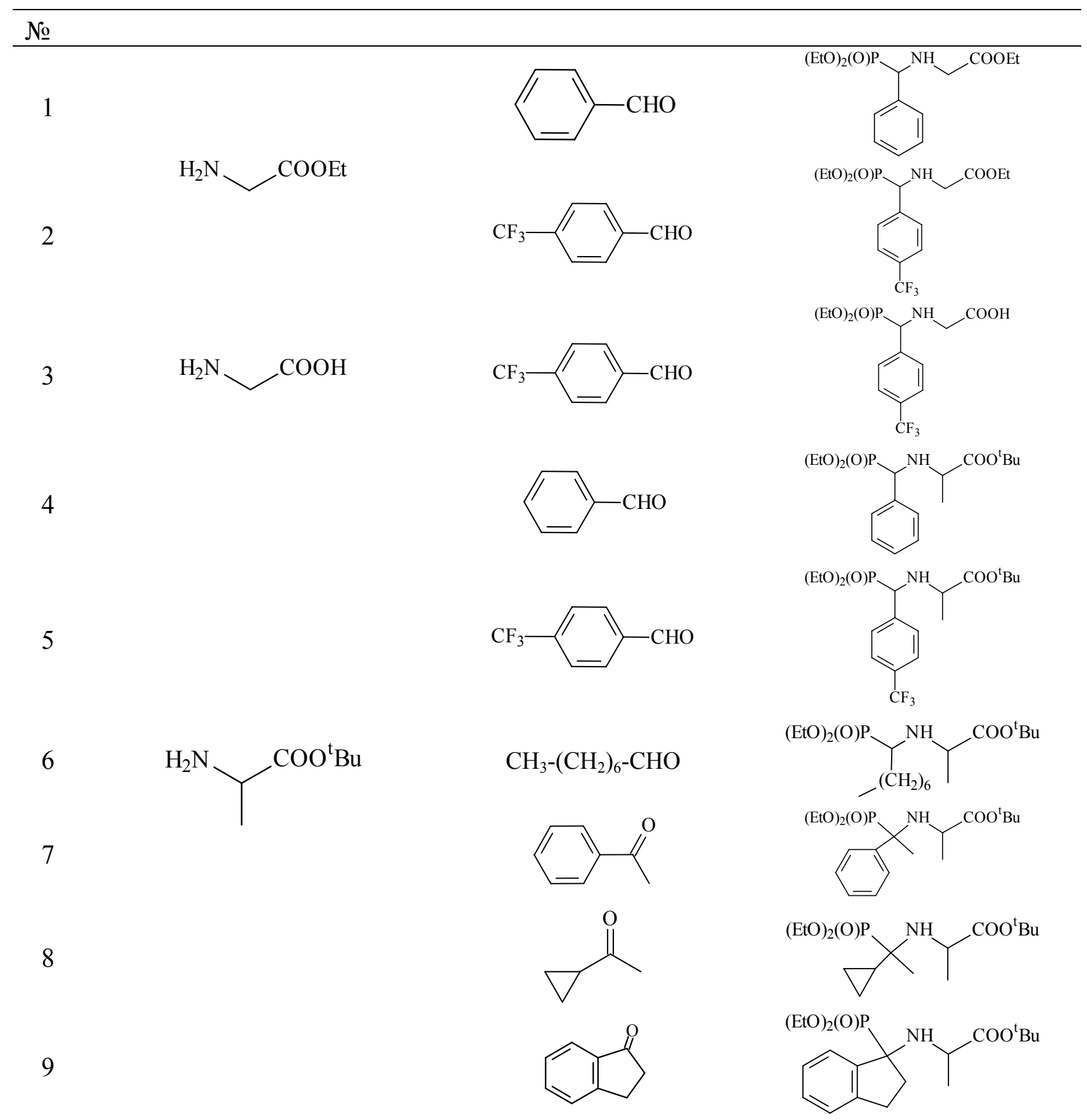


10

11

12

13

14

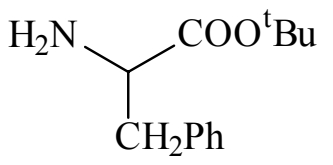

15

16

17

18

19<smiles>NC(Cc1ccccc1)C(=O)O</smiles>

20

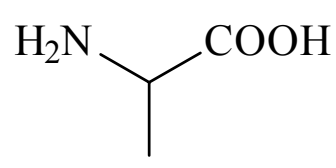

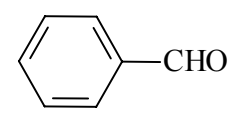
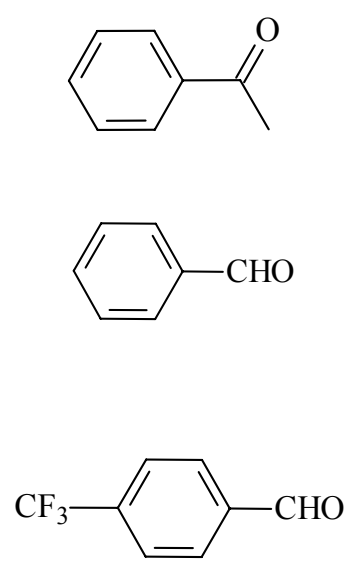

\section{$\mathrm{CH}_{3}-\left(\mathrm{CH}_{2}\right)_{6}-\mathrm{CHO}$}
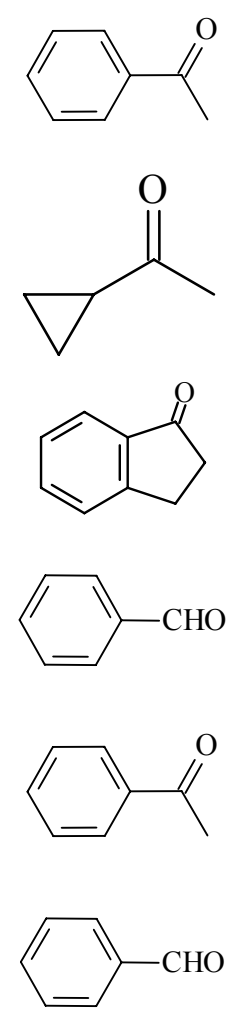
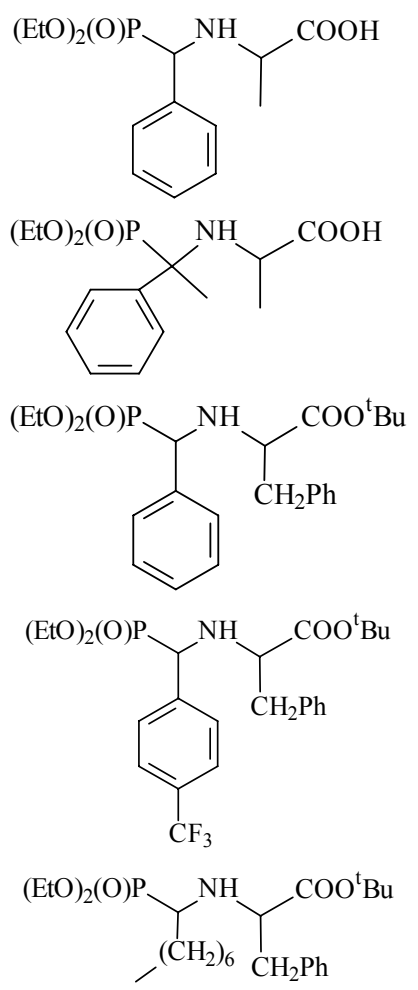<smiles>CCOC(=O)C(Cc1ccccc1)NC(C)(PC(C)(C)C)c1ccccc1</smiles><smiles>CCOC(=O)C(Cc1ccccc1)NC(C)(C(=O)OCC)C1CC1</smiles>

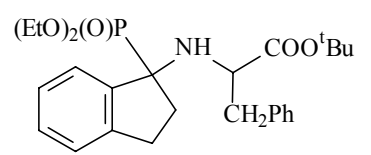<smiles>CCCCC(NC(COCC)c1ccccc1)C(=O)O</smiles><smiles>CCCC(C)(NC(CC)C(=O)O)c1ccccc1</smiles>

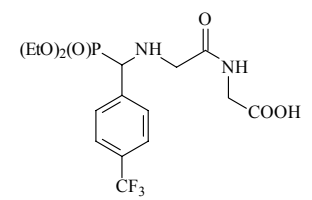


21<smiles>CC(C)CC(NC(=O)CN)C(=O)O</smiles>

22<smiles>N=C(N)NCCCC(N)C(=O)O</smiles>

23

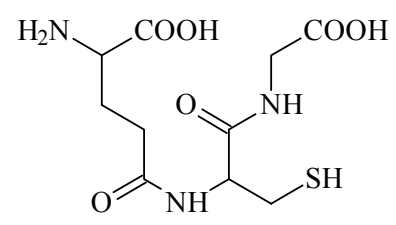

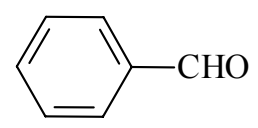
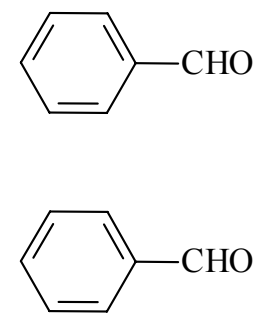
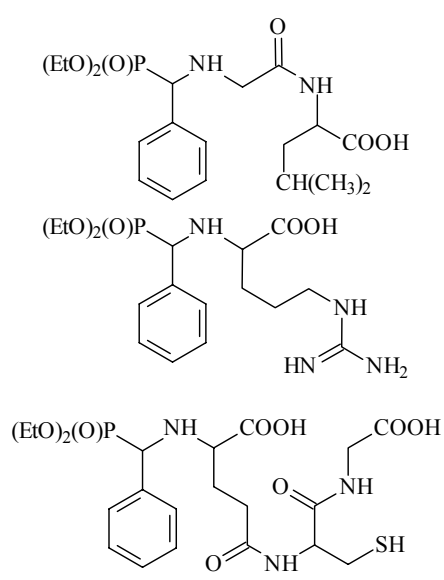

(e) Miscellaneous amino compounds. While the example 22 of the Table 3 shows that not every amino group can play a role of amino component in this reaction; the extension of the process to other structural classes containing $-\mathrm{NH}_{2}$ group is obviously attractive and important.

Our preliminary attempt to involve hydrazines and hydroxylamine ethers in this process were encouraging and these reactions are now under investigation.

\section{Conclusions}

We have shown that our catalytic variant of the Kabachnik-Fields reaction sufficiently increases its synthetic potential. Recent improvements and developments have been connected with systematic search of (i) novel conditions (micro reactor) ${ }^{25 a}$, (ii) reaction without solvent ${ }^{25 b, c}$ and (iii) novel catalysts $\left[\mathrm{Mg}\left(\mathrm{ClO}_{4}\right)_{2},{ }^{25 \mathrm{~b}, \mathrm{c}} \mathrm{p}-\mathrm{TsOH},{ }^{25 \mathrm{~d}} \mathrm{In}(\mathrm{OTf})_{3}-\mathrm{MgSO}_{4},{ }^{15 \mathrm{~b}} \mathrm{CdI}_{2}{ }^{25 \mathrm{e}}\right]$. Most of the new catalysts were applied to aldehydes, and the reaction with ketones was demonstrated only for few cases. Anyhow a comparative study is necessary to select the best catalyst, taking into account a great variety of possibilities. Another future development will probably be connected with the involvement of new classes of organic compounds as the components of this valuable reaction.

\section{References and Footnotes}

1. Sheridan, R. P. J. Chem. Inf. Comput. Sci. 2002, 42, 103.

2. (a) Skopeta, D.; Schworer, R.; Schmodt, R. Bioorg. Med. Chem. Lett. 2003, 13, 3351. (b) Grembecka, J.; Mucha, A.; Cierpicki, T.; Kafarski, P. J. Med. Chem. 2003, 46, 2641. (c) Moore, J. D.; Sprott, K. T.; Hanson, P. R. J. Org. Chem. 2002, 67, 8123. (d) Liu, W.; Rogers, C. J.; Fisher, A. J.; Toney, M. Biochemistry 2002, 41, 12320. (e) Kafarski, P.; Lejczak, B. Curr. Med. Chem: Anti-Cancer Agents. 2001, 1, 301. (f) Dixneuf, P. H. Synlett 
2000, 1031. (g) Ranu, B. C.; Hajra, A.; Jana U. Org. Lett. 1999, 1, 1141. (h) Kim, K. S.; Hurh, E. Y.; Youn, J. N.; Park, J. I. J. Org. Chem. 1999, 64, 9272. (j) Bird, J.; De Mello, R. C.; Harper, G. P.; Hunter, D. J.; Karran, E. H.; Markwell, R. E.; Miles-Williams, A. J.; Rahman, S. S.; Ward, R. W. J. Med. Chem. 1994, 37, 158. (k) Hirschman, R.; Smith, A.; Taylor, C.; Benkovic, P.; Taylor, S.; Yager, K.; Spengler, P.; Venkovic, S. Science 1994, 265, 234. (1) McLeod, D. A.; Brinkworth, R. I.; Ashley, J. A.; Janda, K. D.; Wirsching, P. Bioorg. Med. Chem. Lett. 1991, 653. (m) Allen, M.C.; Fuhrer, W.; Tuck, B.; Wade, R.; Wood, J. J. Med. Chem. 1989, 32, 1652. (n) Atherton, F.; Hassall, C.; Lambert, R. J. Med. Chem. 1986, 29, 29. (o) Kukhar, V. P.; Hudson, H. R. Amonophosphonic and Aminophosphinic Acids: Chemistry and Biological Activity; Kukhar, V. P., Ed.; Wiley: New York, 2000.

3. (a) Bhagat, S.; Chakraborti A. J. Org. Chem. 2007, 72, 1263. (b) Palacios, F.; Vicario, J.; Maliszewska, A.; Aparicio, D. J. Org. Chem. 2007, 72, 2682. (c) Chandrasekhar, S.; Prakhash, S.; Jagadeshwar, V.; Narsihmulu, C. Tetrahedron Lett. 2001, 42, 5561. (d) Manabe, K.; Kobayashi, S. Chem. Commun. 2000, 669; (e) Uziel, J.; Genet, J. P. Zhur. Org. Khim. (Russian Journal of Organic Chemistry) 1997, 33, 1605. (f) Gancarz, R.; Wieczorek, J. Synthesis 1978, 625. (g) Seyfert, D.; Marmor, R.; Hilbert, P. J. Org. Chem. 1971, 36, 1379. (h) Barycki, J.; Mastalerz, P.; Soroka, M. Tetrahedron Lett. 1970, 3, 3147.

4. Pudovik A. N. Doklady Akad. Nauk SSSR, 1952, 83, 865; Chem. Abstr. 1953, 47, 4300.

5. (a) Abramov, V. S. Doklady Akad. Nauk SSSR 1950, 73, 487. (b) Pudovik A. N.; Guriynova I. V.; Ishmaeva, E. A. Reaction and Investigation Methods in Organic Chemistry (Russ); Khimija: Moscow, 1968; pp 7. (c) Kolodiyjnui O. I. Usp. Khim. (Russ. Chem. Rev), 2006, $75,254$.

6. (a) Kabachnik, M. I.; Medved, T. Ya. Dokl. Akad. Nauk SSSR 1952, 83, 689; Chem. Abstr. 1953, 47, 2724. (b) Kabachnik, M. I.; Medved, T. Ya. Izv. Akad. Nauk SSSR, Ser. Chim. 1953, 1126; idem, ibid. 1954, 1024. (c) Fields, E. J. Am. Chem. Soc. 1952, 74, 1528.

7. Review see: Cherkasov, R. A.; Galkin, V. I. Russ. Chem. Rev. 1998, 67, 857; Chem. Abstr. 1953, 47, 2724b.

8. LaPointe, A. M. J. Comb. Chem. 1999, 1, 101.

9. (a) Kotovich, Zhur. Obshch. Khim. 1987, 57, 1416. (b) Gancarz, R. Tetrahedron 1995, 51, 10627.

10. (a) Matveeva, E. D.; Podrugina, T. A.; Tishkovskaya E. V.; Tomilova, L. G.; Zefirov, N. S. Synlett 2003, 2321. (b) Matveeva, E. D.; Podrugina, T. A.; Prisyajnoy, M. V.; Zefirov, N. S. Abstracts of Int. Symposium Advances in Synthetic, Combinatorial and Medicinal Chemistry, Moscow, 2004, pp 130; (c) Matveeva, E. D.; Podrugina, T. A.; Prisyajnoy, M. V.; Zefirov, N. S. Abstracts of Int. Conference Perspective of Chem. Development and Industrial Appl. of Alicyclic Compounds, Samara (Russia), 2004, pp 203. (d) Matveeva, E. D.; Podrugina, T. A.; Prisyajnoy, M. V.; Zefirov, N. S. Zhur. Org. Khim. 2006, 42, 1164. (e) Matveeva, E. D.; Podrugina, T. A.; Zefirov, N. S. Abstracts of Papers $230^{\text {th }}$ ACS National Meeting, Washington, DC, USA, 2005, ORGN-118. (f) Matveeva, E. D.; Zefirov, N. S. 
Zhur. Org. Khim. 2006, 42, 1254. (g) Matveeva, E. D.; Podrugina, T. A.; Prisyajnoy, M. V.; Zefirov, N. S. Izv .AN Ser. Khim. 2006, 1164. (h) Zefirov, N. S. Matveeva, E. D. Abstracts of Int. Symposium Organic Chemistry, Present and Future, Louvain-la-Neuve, Belgium, 2007, P-135. (i) Matveeva, E. D.; Podrugina, T. A.; Prisyajnoy, M. V.; Rusetzkaja, I. N.; Zefirov, N. S. Isv. Akad. Nauk (Russ), ser.khim. 2007, 768.

11. (a) Galkina, I. V.; Zvereva, E. R.; Galkin, V. I.; Cherkasov, R. A. Zhur. Obshch. Khim. (Russian Journal of General Chemistry) 1998, 68, 1457. (b) Galkina, I. V.; Zvereva, E. R.; Galkin, V. I.; Sobanov, A. A.; Cherkasov, R. A Zhur. Obshch. Khim. 1998, 68, 1453. (c) Galkina, I. V.; Sobanov, A. A.; Galkin, V. I.; Cherkasov, R. A Zhur. Obshch. Khim. 1998, 68, 1465. (e) Galkina, I. V.; Galkin, V. I.; Cherkasov, R. A Zhur. Obshch. Khim. 1998, 68, 1469.

12. Dimukhametov, M. N.; Bayandina, E. V.; Davydova, E. Yu.; Gubaidullin, A. T.; Litvinov, I. A.; Alfonsov, V. A. Mendeleev Communications 2003, 150.

13. (a) Kaboudin, B.; Nazari, R. Tetrahedron Lett. 2001, 42, 8211. (b) Yadav, J. S.; Reddy, B.; Madam, C. Synlett 2001, 1121. (c) Lee, S; Lee, J; Song, C; Kim, D. Bull. Korean Chem. Soc. 2002, 23, 667. (d) Reinhold, G.; Kiddle, J.J.; Guerin, M. Abstracts, 35th Great Lakes Regional Meeting of the ACS, Chicago, May 31-June 2, 2003. (e) Mu, X.; Lei, M.; Zou, J.; Zhang, Wi. Tet. Lett. 2006, 47, 1125.

14. (a) Yadav, J. S.; Reddy, B.; Sreedhar, P. Green Chem. 2002, 4, 436. (b) Lee, S.; Park, J. Kang, J.; Lee, J. Chem. Commun. 2001, 1698. (c) Lee Sang-gi, Park J. H.; Kang J.; Lee J. K. Chem. Commum. 2001, 1698.

15. (a) Qian, C.; Huang, T. J. Org. Chem. 1998, 63, 4125. (b) Ghosh, R.; Maiti, S.; Chakraborty, A., Maiti, D. J. Mol. Catal. A, 2004, 210, 53. (c) Xu, F.; Luo, Y.; Deng, M.; Shen, Q. Eur. J. Org. Chem. 2003, 4728.

16. (a) Petrov, Usp. Khim. 1974, 43, 2045. (b) Zon, J.; Pol. J. Chem. 1981, 55, 643. (c) Laschat, S.; Kunz, H. Synthesis 1992, 90.

17. (a) Frouzabadi, H.; Iranpoor, H.; Sobhani, S. Synthesis 2004, 2692. (b) Ranu, B.; Hajra, A.; Jana, U. Org. Lett. 1999, 1, 1141. (c) Manabe, K.; Kobayashi, S. Chem. Commum. 2000, 669. (d) Chanrasekhar, S.; Prakash, S.; Jagadeshwar, V.; Narsihmulu, C. Tetrahedron Lett. 2001, 42, 5561. (e) Manjula, A.; Rao, B.; Neelakantan, P. Synth. Commun. 2003, 33, 2963.

18. (a) Krutikov, V. I.; Sukhanovskaya, E. V.; Tsarkova, I. A. Zhur. Obshch.Khim. 1992, 62, 2708. (b) Grozav, M.; Neamitu, I.; Doresencu, M. Revista de Chimie (Romania) 2001, 52, 693. (c) Yadav Synlett 2001, 1131. (d) Zhan, Z.; Yang. R.; Li, J. Chem. Lett. 2005, 34, 1042. (e) Joly, G.; Jacobsen, E. J. Am. Chem. Soc. 2004, 126, 4102. (f) Kaboudin, B.; Moradi, K. Tetrahedron Lett. 2005, 46, 1209.

19. Sadarian, A. R.; Kaboudin, B. Tetrahedron Lett. 1997, 38, 2543.

20. (a) Petrov, P.; Valceanu, R.; Vlad, F-I.; Muresan, Revista de Chimie (Bucharest) 1995, 46, 977. (b) Bailly, T.; Burgada, R. Phosphorus, Sulfur, Silicon and the Related Elements 1995, 101, 131. (c) Yurchenko, R. I.; Voitsekhovskaya, O. M.; Klepa, T. I.; Yurchenko, A. G. Zhur. Obshch. Khim. 1995, 65, 1449. (d) Remizov, A. S.; Koroleva, T. I.; Promonenkov, V. 
K.; Grapov, A. F. Zhur. Obshch. Khim. 1981, 51, 341. (e) Krutikov, V. I.; Kovalenko, A. L.; Sukhanovskaya, E. V.; Tsar'kova, I. A.; Lavrent'ev, A. N. Zhur. Obshch. Khim. 1992, 62, 556. (f) Dimukhametov, M. N.; Galieva, L. F.; Shlyamina, O. V.; Levinson, F. S.; Al'fonsov, V. A., Zhur. Obshch. Khim. 1998, 68, 1554. (g) Matevosyan, G. L.; Yukha, Yu. S.; Zavlin, P. M., Zhur. Obshch. Khim. 2003, 73, 1822. (h) Menard, L.; Fontaine, L.; Brosse, J. Reactive Polymers 1994, 23, 201. (j) Antipin, I. S.; Stoikov, I. I.; Pinkhassik, E. M.; Fitseva, N. A.; Stibor, I.; Konovalov, A. I. Tet. Lett. 1997, 38, 5865.

21. Prishchenko, A. A.; Novikova, O. N.; Livanzov, M. V.; Grigor'ev, E. V.; Goncharova, Zh. Yu. Zhur. Obshch. Khim. 1995, 65, 1751.

22. Matevosyan, G. L.; Zhuravlev, A. V.; Zavlin, P. M. Zhur. Obshch. Khim. 1983, 53, 2401.

23. (a) Cristau, H-J.; Coulombeau, A.; Genevois, A.; Sanchez, F.; Pirat, J-L., J. Organomet. Chem. 2002, 643, 381. (b) Trishin, Yu. G.; Maslov, V. I. Russ. Chem. Bull. (Translation of Izvestiya Akademii Nauk, Seriya Khimicheskaya), 1998, 47, 2047. (c) Cristau, H-J.; Herve, A.; Vireieux, D. Tetrahedron 2004, 60, 877. (d) Prishchenko, A. A.; Livanzov, M. V.; Kustrja, B.N.; Grigor,rv, E. V. Zhur. Obshch. Khim. 1995, 65, 1753. (e) Rozhko, L. F.; Ragulin, V. V. Amino Acids 2005, 29, 139.

24. Gancarz, R. Phosphorus, Sulfur, Silicon Rel. Elements 1993, 83(1-4), 59.

25. (a) Van Meenen, E.; Moonen, K.; Acke, D.; Stevens, C. ARKIVOC 2006, (i), 31. (b) Bhagat, S.; Chakraborti, A. K. J. Org. Chem. 2007, 72, 1263. (c) Jie Wu, Wei Sun, Hong-Guang Xia, Xiaoyu Sun. Org. Biomol .Chem. 2006, 4, 1663. (d) Kaboudin, B. Moradi, K. Tetrahedron Lett. 2005, 46, 2989. (e) Kabachnik M. M., Zobnina E. V., Beletskaya I. P. Zhur. Org. Khim. 2005, 517.

\section{Authors' biographies}

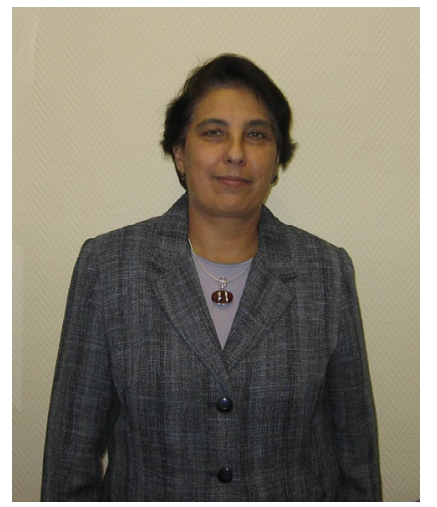

Elena D. Matveeva was born in 1945 in Tashkent, Uzbekistan. She did her graduate studies and post graduation course at Moscow State University( Ph.D. 1972). She was a junior researcher in Moscow State University (1971-1979). In 1977 she was a postdoctoral research fellow of Gent State University, Department of Organic Chemistry (Belgium). From 1980 she is the Assistant, 
and from 1988-Associated Professor of Organic Chemistry Department, Moscow State University. She has over 110 publications.

Her scientific interests concern synthesis and prototropic rearrangments in heterocyclic, macrocyclic compounds, stereo-regiospecific synthesis of pheromones, novel phosphoruscontaining-halogenophilic reagents in nucleophilic substitution. Her recent research is related to the development of a new catalytic approach to the synthesis of peptidomimetics - potential ligands of glutamate receptors and potentially new medical drugs. Another research field is related to the study of structure and reactivity of the mixed ylides of iodine and phosphorus, with the purpose of developing, on this basis, a new methodology of synthesis of potential biologically active compounds.

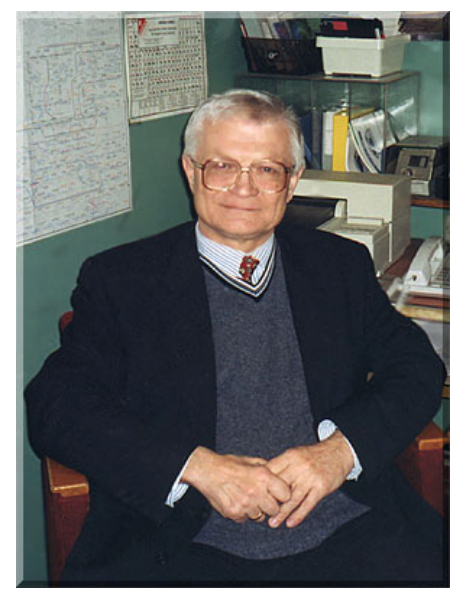

Nikolai S. Zefirov, is a member of Russian Academy of Science, a Director of Institute of Physiologically Active Compounds of Russian Academy of Sciences, a member of International Academy of Mathematical Chemistry, Professor of Moscow State University, and the Head of Organic Chemistry Division in the Department of Chemistry. His research interests are in the areas of (1) Mathematical chemistry, theoretical design of novel structures and reactions, (2) Synthesis of new organic structures; experimental design of new organic reagents and reactions, and (3) Medicinal chemistry and research in the field of physiologically active compounds. 